\title{
The Mangrove Landscape and Zonation Following Soil Properties and Water Inundation Distribution in Segara Anakan Cilacap
}

\author{
Endang Hilmi $^{1^{*}}$, Amron², Lilik Kartika Sari ${ }^{1}$, Tri Nur Cahyo ${ }^{2}$, Asrul Sahri Siregar ${ }^{3}$
}

\begin{abstract}
${ }^{1}$ Aquatic Resources Management Program and Magister of Aquatic Resources, Fisheries and Marine Sciences Faculty-Jenderal Soedirman University, Kampus Perikanan UNSOED Karangwangkal, Jl. dr. Suparno, Purwokerto, Indonesia 53123 ${ }^{2}$ Marine Science Program, Fisheries and Marine Sciences Faculty-Jenderal Soedirman University, Kampus Perikanan UNSOED Karangwangkal, Jl. dr. Suparno, Purwokerto, Indonesia 53123

${ }^{3}$ Aquatic Resources Management Program, Fisheries and Marine Sciences Faculty-Jenderal Soedirman University, Kampus Perikanan UNSOED Karangwangkal, Jl. dr. Suparno, Purwokerto, Indonesia 53123
\end{abstract}

Received November 15, 2020/Accepted October 28, 2021

\begin{abstract}
The mangrove zoning and landscape express the correlation between mangrove vegetation (density, biodiversity and species distribution) with environment factors like as water inundation, seatide, and soil properties. The research was conducted in Segara Anakan Lagoon to analysis community structure and mangrove landscape based on species distribution, biodiversity, environment factors, and mangrove zoning. The results showed that (a) Segara Anakan Lagoon had 4 mangrove zone's were dominated by Sonneratia alba, Rhizophora mucronata, Avicennia marina, Rhizophora apiculata, Rhizophora styllosa, and Nypa frutican; (b) the structure of ecosystem was showed by trend of mangrove ecosystem with equation $y=35.34 x^{2} 923.85 x+12817$ with $x=$ time (year) and $y=$ mangrove area $($ ha $)$, mangrove density between 1333367 ind ha ${ }^{-1}$ (West Segara Anakan) and 899-567 ind ha ${ }^{-1}$ (East Segara Anakan), dominated species were Nypa frutican, Rhizophora stylosa, Rhizophora apiculata, and Aegiceras corniculatum and mangrove biodiversity between 2,572,65 (moderate); (c) structure of environment factor showed single and semi double-type tides, water debit between $0.360 .73 \mathrm{~m} \mathrm{~s}^{-1}$; water depth between $0.20-23.7 \mathrm{~m}$ and water inundation between $480 \mathrm{~cm}$; soil texture was clay and loam, soil nitrate of $1.5 \mathrm{mg} 100 \mathrm{~g}^{-1}$, soil phosphate of $1.5 \mathrm{mg} 100 \mathrm{~g}^{-1}$, C organic of $1.31 \%$, soil pH of 6-7, and soil salinity of 6.5-10 ppt.
\end{abstract}

Keywords: community structure, mangrove landscape, mangrove density, environment factors, dominated species

*Correspondence author, email: dr.endanghilmi@gmail.com, tel.+62-281-638793,fax.+62-281-638793

\section{Introduction}

Segara Anakan Lagoon is a semi-closed seawater ecosystem since preserved by Nusakambangan Islands, and takes the seawater supply from the Indian Ocean and freshwater supply from many rivers like as Donan, Citanduy, Cikonde, and Sapuregel river (Hilmi et al., 2019a; 2020). This condition is a trigering factor to support potential of seatide, water inundation, $\mathrm{pH}$, salinity, soil texture, and soil fertilize. The potential of soil and water factors give impact toward the mangrove zonasi and landscape in Segara Anakan Lagoon. This conditions also show the abnormal of mangrove structure and zoning in this mangrove ecosystem (Sinfuego \& Buot, 2014; Datta \& Deb, 2017).

Basically, mangrove zonation describe a specific structure of mangrove ecosystem using variables of species disribution, species density, and environment factors. The mangrove zone and landscape are influenced by water salinity (Hoppe-Speer et al., 2011; Kantharajan et al., 2018), soil factor (Domínguez-domínguez et al., 2019), soil salinity, $\mathrm{pH}$, soil fertility, water quality (Shiau et al., 2017a; Hilmi et al., 2019b), soil texture (Khadim et al., 2019), sea tide, sea current, seawater inundation, phosphate, sulfate, nitrate and nitrogen (Shiau et al., 2017a; Cheng et al., 2019), freshwater supply, and soil carbon (Barreto et al., 2016; Dai et al., 2018; Xiong et al., 2018). However, the mangrove landscape following the patern of the mangrove zone, species distribution and structure community also refer to the adaptation of mangrove species toward changing of environment factors (Giri et al., 2015), the potential of sedimentation (de Oliveira et al., 2015; Sari et al., 2016), heavy metal pollution (de Oliveira et al., 2015), nitrate buffers (Liu et al., 2019), and oxygen stress (Asaeda \& Barnuevo, 2019). Mangrove landscape explains the community structure, species zonation (Sreelekshmi et al., 2018), mangrove stability, and health (De Valck \& Rolfe, 2018), mangrove association, and clustering (Hilmi, 2018). In many areas, the mangrove community also is influenced by exsistence of Rhizophora spp., Avicennia spp., Bruguiera spp., Aegiceras spp., Ceriops spp., and Sonneratia spp. as major species of mangrove ecosystem.

Mangrove ecosystem also is influenced by abnormal factors like as sedimentation and pollution. Mangrove species must have the best adaptation patterns to reduce high sedimentation and pollution in Segara Anakan Lagoon. The 
specific adaptation of mangrove species also are developed to reduce impact of mangrove degradation (Ferreira et al., 2015; Kantharajan et al., 2018), sedimentation (Sari et al., 2016), pollution, and minor species expansion (Smee et al., 2017). Based on the data of several research show that in Segara Anakan Lagoon (SAL) has high sedimentation (sediment rate between $4.26103 .60 \mathrm{~g} \mathrm{day}^{-1}$ and total sedimentation 0.228 .05 million ton year ${ }^{-1}$ ) (Sari et al., 2016), mixed semidiurnal tide, seawater current $\left(0.360 .73 \mathrm{~m} \mathrm{~s}^{-1}\right)$, inundation level $(076 \mathrm{~cm})$, water salinity $(30.9934 .01 \mathrm{ppt})$ and $\mathrm{pH}$ (6.767.02) (Sari et al., 2016; Hilmi et al., 2019b) and be dominated species by Rhizophora spp., Avicennia spp., and Nypa frutican. The mangrove landscape and zonation following soil properties and water inundation distribution in Segara Anakan Cilacap is develop by relation among species distribution, biodiversity, mangrove density with environment factors. This paper aimed to analysis mangrove landscape and zone's using mangrove density, mangrove covering, mangrove adaptation and distribution soil properties, oceanography and water quality as main variables.

\section{Methods}

Research area This research was conducted in Segara Anakan Lagoon (SAL) which was arranged by the mangrove, river (Donan River, Sapuregel River, Kembang Kuning River, Citanduy River, Cimeneng River, and Cikonde River), terrestrial and estuary ecosystems (Hilmi et al., 2019a; $2019 \mathrm{~b}$ ), and Nusakambangan Island as perserved area. This research collect data on 37 stations that were 17 stations in Esat Segara Anakan Lagoon/E-SAL which were distributed in Kalipanas, Donan River, Sapuregel, Pelawangan Timur, and Kembang Kuning River, and 20 stations in West Segara Anakan Lagoon/W-SAL were distributed in Ujung Gagak, Majingklak, Klaces, Ujung Alang, and Kali Semak (Table 1 and Figure 1). The research in SAL was conducted between 2019-2021 to analysis mangrove density, soil water, sea tide, and sea water inundation.

Soil water factor analysis The analysis of soil water were (a) soil water salinity (ppt) using the conductive-photometric method/Hand Refractometer, (b) soil pH using Potentiometric method/pH meter (APHA, 2005; 2012); (c)

Table 1 Research stations

\begin{tabular}{|c|c|c|c|c|c|}
\hline \multicolumn{3}{|c|}{ West Segara Anakan } & \multicolumn{3}{|c|}{ East Segara Anakan } \\
\hline \multirow{2}{*}{ Stations } & \multicolumn{2}{|c|}{ Coordinate } & \multirow{2}{*}{ Stations } & \multicolumn{2}{|c|}{ Coordinate } \\
\hline & Latitude (S) & Longitude (E) & & Latitude (S) & Longitude (E) \\
\hline Sungai Ujung Gagak & $07^{\circ} 40^{\prime} 13^{\prime \prime}$ & $108^{\circ} 48^{\prime} 43^{\prime \prime}$ & Kali panas 1 & $07^{\circ} 40^{\prime} 22.17^{\prime \prime}$ & $109^{\circ} 00^{\prime} 56.36^{\prime \prime}$ \\
\hline Sungai Lorogan & $07^{\circ} 40^{\prime} 44^{\prime \prime}$ & $108^{\circ} 48^{\prime} 30^{\prime \prime}$ & Kali panas 2 & $07^{\circ} 40^{\prime} 28.91^{\prime \prime}$ & $109^{\circ} 00^{\prime} 40.57^{\prime \prime}$ \\
\hline Sungai Majingklak & $07^{\circ} 40^{\prime} 32^{\prime \prime}$ & $108^{\circ} 48^{\prime} 01^{\prime \prime}$ & Kali panas 3 & $07^{\circ} 40^{\prime} 20.60^{\prime \prime}$ & $109^{\circ} 00^{\prime} 33.62^{\prime \prime}$ \\
\hline Sungai Mauara Cawitali & $07^{\circ} 41^{\prime} 46^{\prime \prime}$ & $108^{\circ} 47^{\prime} 41^{\prime \prime}$ & Kali panas 4 & $07^{\circ} 40^{\prime} 18.26^{\prime \prime}$ & $109^{\circ} 00^{\prime} 32.52^{\prime \prime}$ \\
\hline Sungai Kebuyutan & $07^{\circ} 41^{\prime} 13^{\prime \prime}$ & $108^{\circ} 47^{\prime} 45^{\prime \prime}$ & Kali panas 5 & $07^{\circ} 40^{\prime} 41.12^{\prime \prime}$ & $109^{\circ} 00^{\prime} 33.98^{\prime \prime}$ \\
\hline Sungai Batu Macan & $07^{\circ} 41^{\prime} 38^{\prime \prime}$ & $108^{\circ} 47^{\prime} 46^{\prime \prime}$ & Donan 1 & $07^{\circ} 40^{\prime} 33.98^{\prime \prime}$ & $108^{\circ} 59^{\prime} 58.10^{\prime \prime}$ \\
\hline Sungai Jongor & $07^{\circ} 40^{\prime} 23^{\prime \prime}$ & $108^{\circ} 48^{\prime} 20^{\prime \prime}$ & Donan 2 & $07^{\circ} 40^{\prime} 23.79^{\prime \prime}$ & $108^{\circ} 59^{\prime} 56.90^{\prime \prime}$ \\
\hline Sungai Muara Legok & $07^{\circ} 39^{\prime} 48^{\prime \prime}$ & $108^{\circ} 48^{\prime} 13^{\prime \prime}$ & Donan 3 & $07^{\circ} 41^{\prime} 15.79^{\prime \prime}$ & $108^{\circ} 59^{\prime} 43.22^{\prime \prime}$ \\
\hline Sungai Kayu Mati & $07^{\circ} 39^{\prime} 50^{\prime \prime}$ & $108^{\circ} 48^{\prime} 27^{\prime \prime}$ & Donan 4 & $07^{\circ} 42^{\prime} 10.17^{\prime \prime}$ & $108^{\circ} 59^{\prime} 23.75^{\prime \prime}$ \\
\hline Sungai Langkap & $07^{\circ} 38^{\prime} 48^{\prime \prime}$ & $108^{\circ} 48^{\prime} 44^{\prime \prime}$ & Donan 5 & $07^{\circ} 42^{\prime} 46.06^{\prime \prime}$ & $108^{\circ} 59^{\prime} 29.10^{\prime \prime}$ \\
\hline Sungai Karang Braja & $07^{\circ} 40^{\prime} 59^{\prime \prime}$ & $108^{\circ} 48^{\prime} 47^{\prime \prime}$ & Donan 6 (Sleko) & $07^{\circ} 43^{\prime} 48.07^{\prime \prime}$ & $108^{\circ} 59^{\prime} 10.78^{\prime \prime}$ \\
\hline Sungai Klaces & $07^{\circ} 41^{\prime} 05^{\prime \prime}$ & $108^{\circ} 49^{\prime} 47^{\prime \prime}$ & Pelawangan Timur & $07^{\circ} 43^{\prime} 20.95^{\prime \prime}$ & $108^{\circ} 58^{\prime} 07.45^{\prime \prime}$ \\
\hline Sungai Inti Ujung Gagak & $07^{\circ} 40^{\prime} 34^{\prime \prime}$ & $108^{\circ} 49^{\prime} 47^{\prime \prime}$ & Sapuregel 1 & $07^{\circ} 41^{\prime} 53.33^{\prime \prime}$ & $108^{\circ} 57^{\prime} 46.71^{\prime \prime}$ \\
\hline Sungai Muara Bagian & $07^{\circ} 40^{\prime} 58^{\prime \prime}$ & $108^{\circ} 51^{\prime} 42^{\prime \prime}$ & Sapuregel 2 & $07^{\circ} 41^{\prime} 47.97^{\prime \prime}$ & $108^{\circ} 57^{\prime} 37.81^{\prime \prime}$ \\
\hline Sungai Muara Masigitsela & $07^{\circ} 41^{\prime} 24^{\prime \prime}$ & $108^{\circ} 50^{\prime} 46^{\prime \prime}$ & Sapuregel 3 & $07^{\circ} 42^{\prime} 54.20^{\prime \prime}$ & $108^{\circ} 57^{\prime} 42.07^{\prime \prime}$ \\
\hline Sungai Pertigaan Ujung Alang & $07^{\circ} 41^{\prime} 44^{\prime \prime}$ & $108^{\circ} 51^{\prime} 39^{\prime \prime}$ & Kembang kuning1 & $07^{\circ} 43^{\prime} 12.88^{\prime \prime}$ & $108^{\circ} 57^{\prime} 14.24^{\prime \prime}$ \\
\hline Sungai Ujung Alang & $07^{\circ} 42^{\prime} 00^{\prime \prime}$ & $108^{\circ} 51^{\prime} 42^{\prime \prime}$ & Kembang kuning2 & $07^{\circ} 43^{\prime} 07.52^{\prime \prime}$ & $108^{\circ} 57^{\prime} 03.97^{\prime \prime}$ \\
\hline Sungai Dermaga Ujung Alang & $07^{\circ} 42^{\prime} 06^{\prime \prime}$ & $108^{\circ} 51^{\prime} 53^{\prime \prime}$ & & & \\
\hline Sungai Kali Semak & $07^{\circ} 42^{\prime} 30^{\prime \prime}$ & $108^{\circ} 52^{\prime} 57^{\prime \prime}$ & & & \\
\hline Sungai Pertigaan Sudiro & $07^{\circ} 42^{\prime} 32^{\prime \prime}$ & $108^{\circ} 53^{\prime} 38^{\prime \prime}$ & & & \\
\hline
\end{tabular}




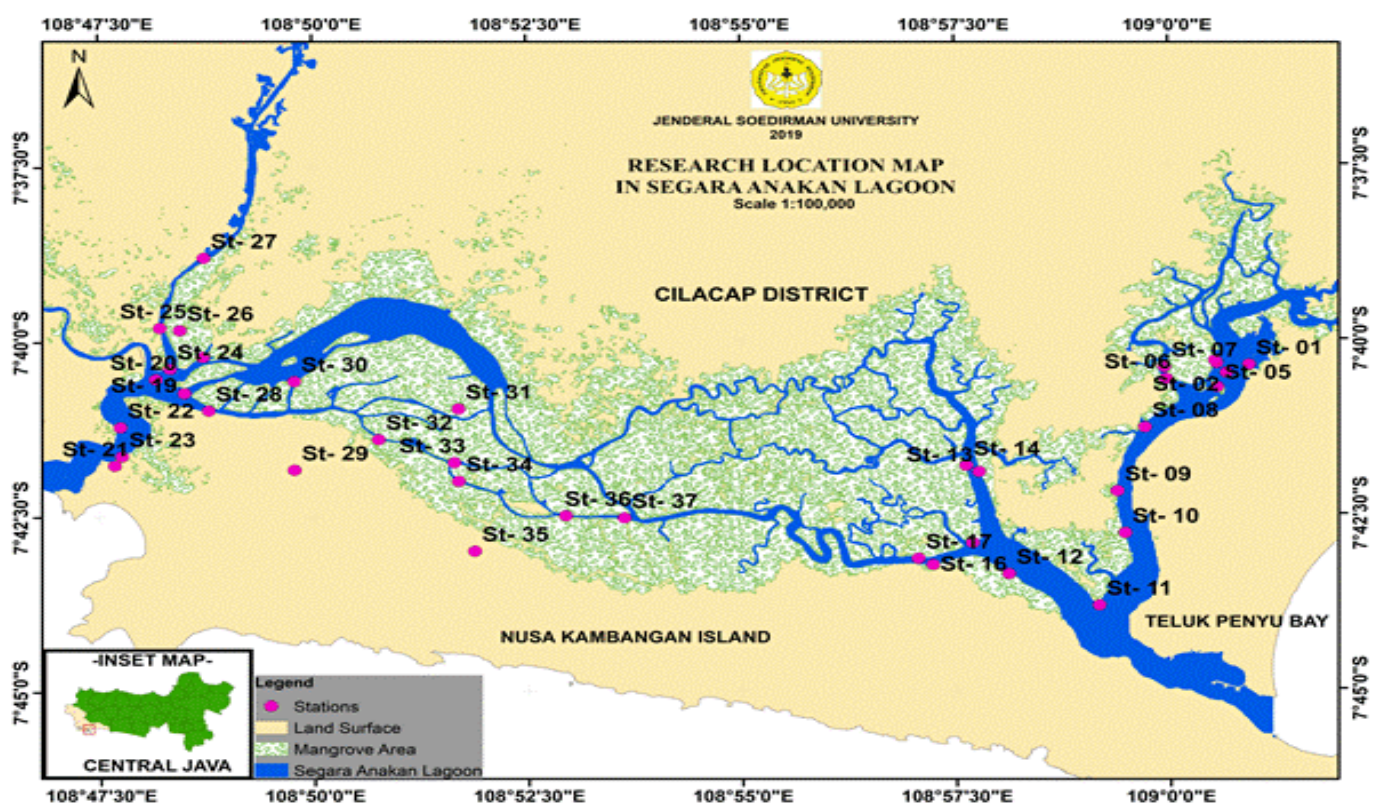

Figure 1 Research area.

Soil texture (\%) using Gravimetric method (APHA, 2005;

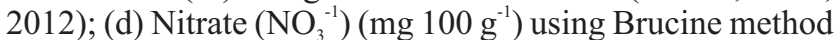
(APHA, 2005; 2012), (e) Phosphate $\left(\mathrm{PO}_{4}^{-3}\right)\left(\mathrm{mg} 100 \mathrm{~g}^{-1}\right)$ using ascorbic acid method (APHA, 2005; 2012); and (f) Organic-C (\%) using Weakly and Black method.

Seatide, currrent speed and seawater inundation Seatide analysis used tidal data of Navigation District Class III Cilacap. The data were first processed using Microsoft Excel with Admiralty tidal behavior calculation method; Current speed used water column current speed measurement with AEM213-D electro-magnetic current meter instrument; Water depth used water column depth measurement method with 2 instruments consisting of multi-beam echo sounder and tin pendulum (dreadloading); and Water inundation $(\mathrm{cm})$ analysis used the tide and inundation stick method to record inundation and tidal scale of stick.

Mangrove density The analysis of mangrove density using mangrove trees with diameter $>4 \mathrm{~cm}$. The collection of mangrove trees used line transect method with a sampling plot with the size of $1010 \mathrm{~m}$. The recording mangrove data were analyzed by density equation following Hilmi et al. (2020) (Table 2).

The data analysis The mapping analysis The mapping analysis used the image processing of satellite imagery between 1990 until 2017. This analysis used a capturing method with ArcGIS version 10.3, ENVI version 4.07, and Google Earth version 2017. To analyze the mangrove landscape, this research used bassic map from the Landsat 7 (1990-2017), Landsat 8 (analysis 20182019), and RBI (2014). The last analysis was mangrove classification used the combined images with false color composite between band 4, 5 and 3 (RGB).
Biodiversity analysis The mangrove biodiversity divided 3 analysis that were species richness, heterogeneity, and evenness index. The mangrove biodiversity analysis used Margaleff index (to analysis species richness), Shannon Wiener index (to analysis heterogenity), and Evennes index (Magurran, 1996).

The statistical analysis Statistical analysis used trend analysis to choice best equation and stock tabulation analysis to develop data structure following value of average, maximum, minimum, and standard deviation (Haslwanter, 2015).

Mangrove landscape analysis The mangrove landscape analysis was used to describe species distribution of mangrove ecosystem in Segara Anakan Lagoon Cilacap. The mangrove landscape was build using the correlation analysis among species density with water depth level $(\mathrm{cm})$, water inundation $(\mathrm{cm}), \mathrm{pH}$, and salinity.

\section{Results and Discussion}

The mangrove zoning The mangrove distribution was showed by the mangrove covering, the species density, the biodiversity and diameter distribution. The mangrove distribution describe the potential area and species of mangrove ecosystem in Segara Anakan Lagoon. The mangrove distribution also showed domination species of mangrove ecosystem in Segara Anakan Lagoon.

The potential of mangrove area The mangrove ecosystem in SAL had the trends consisting of 11,888.3 ha (1990), 8,276.1 ha (1997), 6,928.6 ha (2000), and 7,357.8 ha (2017), whereas lagoon ecosystem had potential were $1,511.5$ ha (1990), 1,493,7 ha (1997), 1,198,7 ha (2000), and 7,357.8 ha (2017) (Figure 2). The trend of mangrove and lagoon ecosystem had 


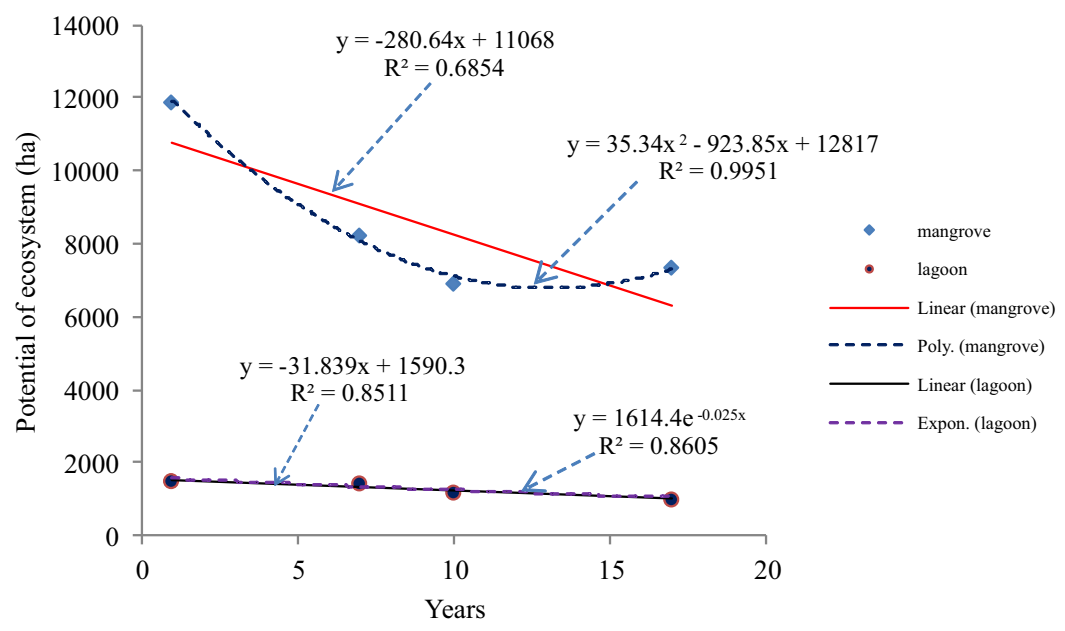

Figure 2 Mangrove distribution trend in Segara Anakan Lagoon.
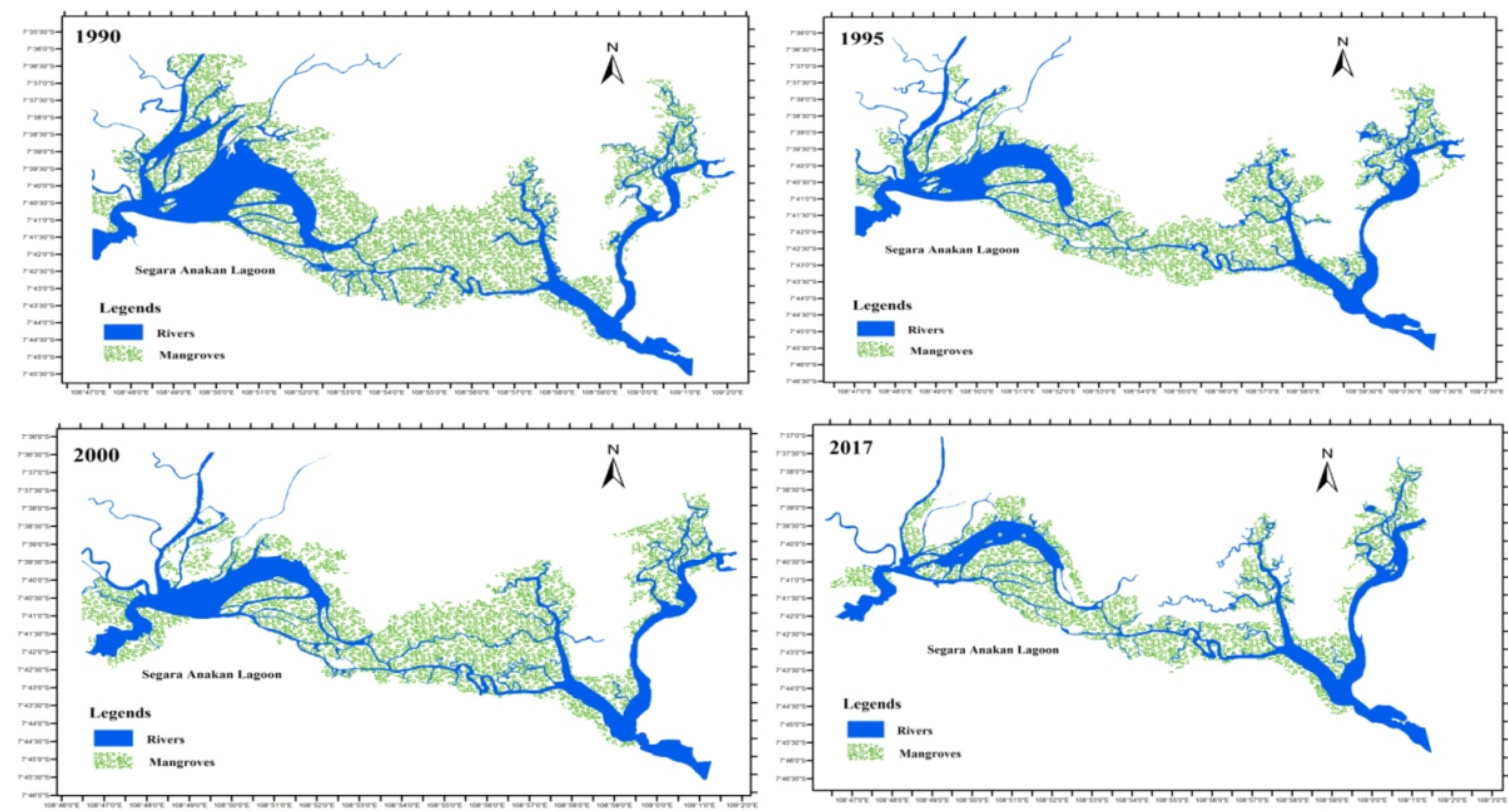

Figure 3 The trend of mangrove distribution in Segara Anakan Lagoon.

negative trend showing the potential degradation of mangrove and lagoon ecosystem in SAL.

The data on Figure 2 and Figure 3 expressed the fast rate of mangrove destruction in Segara Anakan. The prediction model using best regression model and linier model predicted that potential of mangrove ecostystem in Segara Anakan Lagoon $\leq 5,174,6$ ha and potential lagoon $\leq 950.5 \mathrm{ha}$. Xin et al. (2014) also gives note that more than $1 / 3$ total area of mangrove in India, Indonesia, Sri Lanka, Thailand, and China were degraded.

The prediction analysis on Figure 2 and Figure 3 described that the degradation rate of mangrove ecosystem in Segara Anakan Lagoon reached 108.87-251,7 ha year ${ }^{-1}$, and lagoon ecosystem reached 26.0-30.0 ha year ${ }^{-1}$ The mangrove and lagoon degradation in Segara Anakan Lagoon were caused by conversions to fishponds, settlements and industries, ilegal logging, expansion of Acanthus (Ardli \&
Wolff, 2008), sedimentation (Sari et al., 2016), waste pollution disposal and hydrocarbon (Hidayati et al., 2011; Syakti et al., 2013a; 2013b), and accretion (Hilmi et al., 2017). Singh et al. (2013), Victor et al. (2006), and Schwarzer et al. (2016) also estimate the degradation of mangrove ecosystem is caused by conversion, illegal logging, sedimentation, and water pollution including heavy metal pollution

The mangrove density The structure of mangrove density was expressed by mangrove species density and mangrove area. The density of mangrove area was showed by Figure 4 and Table 2. The data showed that potential mangrove density in Segara Anakan Lagoon divided (a) East Segara Anakan Lagoon (E-SAL) between 8995,675 trees ha ${ }^{-1}$, with average 3047 trees ha $^{-1}$, and West Segara Anakan Lagoon (WSAL) had density between 1333,367 trees ha ${ }^{-1}$, with average 


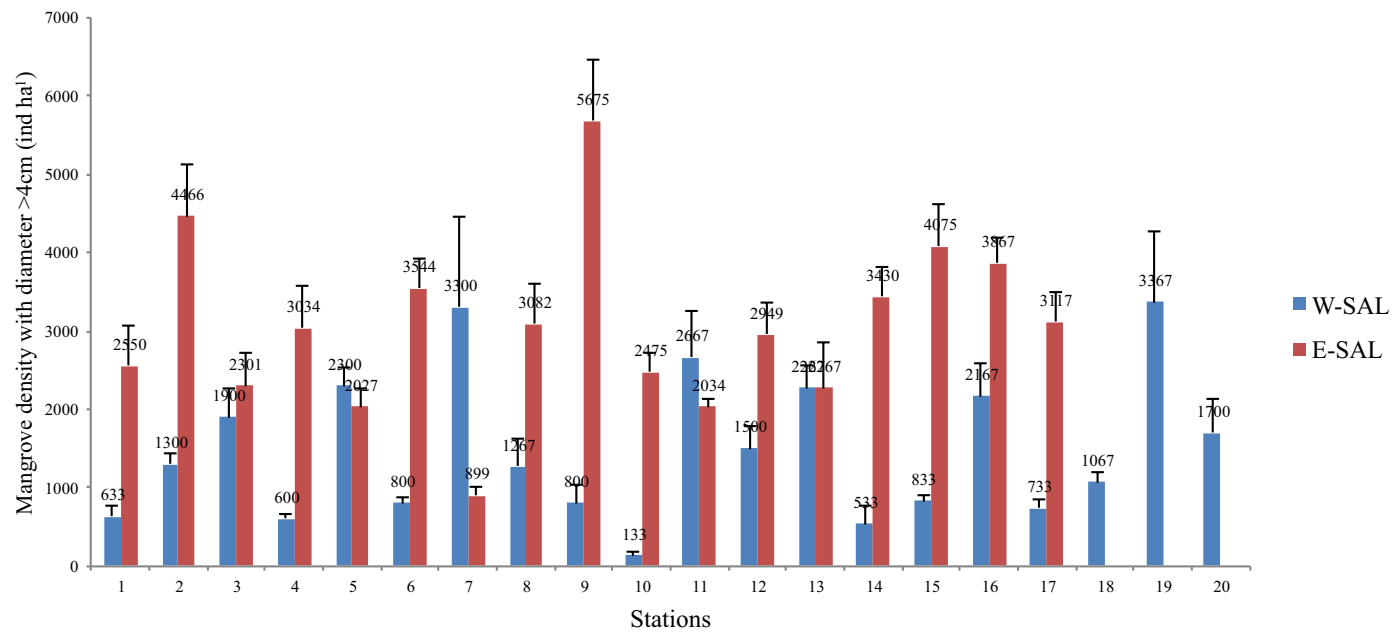

Figure 4 The density of mangrove ecosystem in Segara Anakan Lagoon.

Table 2 Classification of mangrove density levels

\begin{tabular}{lc}
\hline Density level & $\begin{array}{c}\text { Mangrove density }(\text { diameter }>4 \mathrm{~cm}) \\
\text { trees ha }{ }^{-1}\end{array}$ \\
\hline Very rare ly & $0-390$ \\
Rare density & $391-1,610$ \\
Moderate & $1,611-2,220$ \\
High density & $2,221-3,130$ \\
Very high density & $>3,130$ \\
\hline
\end{tabular}

1493 trees $\mathrm{ha}^{-1}$. Potential density of mangrove ecosystem in E-SAL more than mangrove ecosystem in W-SAL. The indicators of mangrove degaradation are showed by the narrowing area of lagoon, loosing of organism habitats, expansion of Acanthus spp., and Acrossticum aureum (Hilmi et al., 2019a; 2020). The others impact are decreasing of fisherman incomes, aquaculture productivity, distrubed transportation, death of organsim aquatic, and othres.

However, the species density of mangrove ecosystem in SAL could be shown on Figure 5. The data showed that ESAL was dominated by $N$. frutican (average 934 trees $^{-1}{ }^{-1}$ ), Rhizophora stylosa (average 733 trees ha ${ }^{-1}$ ), Aegiceras corniculatum (average 471 trees $\mathrm{ha}^{-1}$ ), and $R$. apiculata (average 395 trees $^{-1}$ ). Whereas, W-SAL was dominated by $N$. frutican (average 753 trees $\mathrm{ha}^{-1}$ ), Avicennia marina (average 305 trees $^{-1}$ ), and A. corniculatum (average 283 trees ha' ${ }^{-1}$.

The mangrove density and species distribution in SAL could be shown on Table 2. The data explain that mangrove density in E-SAL more dense than W-SAL. The mangrove ecosystem in E-SAL was dominated by high density and very high denity $(70.6 \%)$, whereas $\mathrm{W}-\mathrm{SAL}$ is dominated by rare density $(55.0 \%)$. The species dominant in SAL were Sonneratia alba, R. mucronata, A. marina, $R$. apiculata, $R$. styllosa, and $N$. frutican.

The distribution of species density in mangrove ecosystem SAL could be shown on Figure 6 . The data on Figure 6 showed that the highest distribution of species density in W-SAL were N. frutican, A. alba, A. marina, and $S$. alba. Whereas the highest distribution of species density in E-SAL were $N$. frutican, $S$. alba, $R$. styllosa, $A$. corniculatum, A. marina and $R$. apiculata.

Hilmi et al. (2015) also noted that mangrove zonation in E-SAL was dominated by $A$. marina and $A$. oficinallis (Zone 1), R. mucronata, R. apiculata, and Ceriops tagal (zone 2) and $N$. fruticans and $S$. casseolaris (Zone 3 ) with diversity index between 0.48-1.83 (low-middle). Hilmi et al. (2017) also noted that the carbon potency of mangrove ecosystem in SAL is influenced by exsistence of Bruguiera praviflora, $R$. mucronata, B. sexangula, R. apiculata, B. gymnorrhiza as major species in mangrove ecosystem.

Mangrove diversity and diameter distribution The last indicator of community structure is the mangrove diversity and diameter distribution will be shown on Table 3. Based on the mangrove diversity showed that Segara Anakan Cilacap had moderate diversity both of species richness and heterogenity but had homogen distribution. However, based on diameter distribution showed that mangrove ecosystem in Segara Anakan had highest diameter distribution between 0-10 cm (Table 4).

The trigerring factors of mangrove zone Sea tide, water depth and water current The lagoon ecosystem in Segara Anakan had the semi diurnal until mixed prevailing semidiurnal of sea tides (in Eastern SAL) and mixed prevailing semi-diurnal of sea tides (in Western SAL), water debit or current speed of between $0.210 .87 \mathrm{~m} \mathrm{~s}^{-1}$ and water depth of between $0.24-20.17 \mathrm{~m}$ (Table 5 and Figure 7). The research of Anthony (2004) notes that the river debit data of more than $0.2 \mathrm{~m} \mathrm{~s}^{-1}$ which is not different with that of Segara Anakan.

The first indicator is the sea tide types. Based on the Formzahl value, Segara Anakan Lagoon has semi diurnal to mixed prevailing semi-diurnal tide with different (asymmetric) shapes between the first and the second tide. The data range between $10403 \mathrm{~cm}$ (sea tide) and $30157 \mathrm{~cm}$ (MSL). This condition caused the river and tidal debit still lower than $1 \mathrm{~m} \mathrm{~s}^{-1}$ (Mazda et al., 2007). The second indicators 


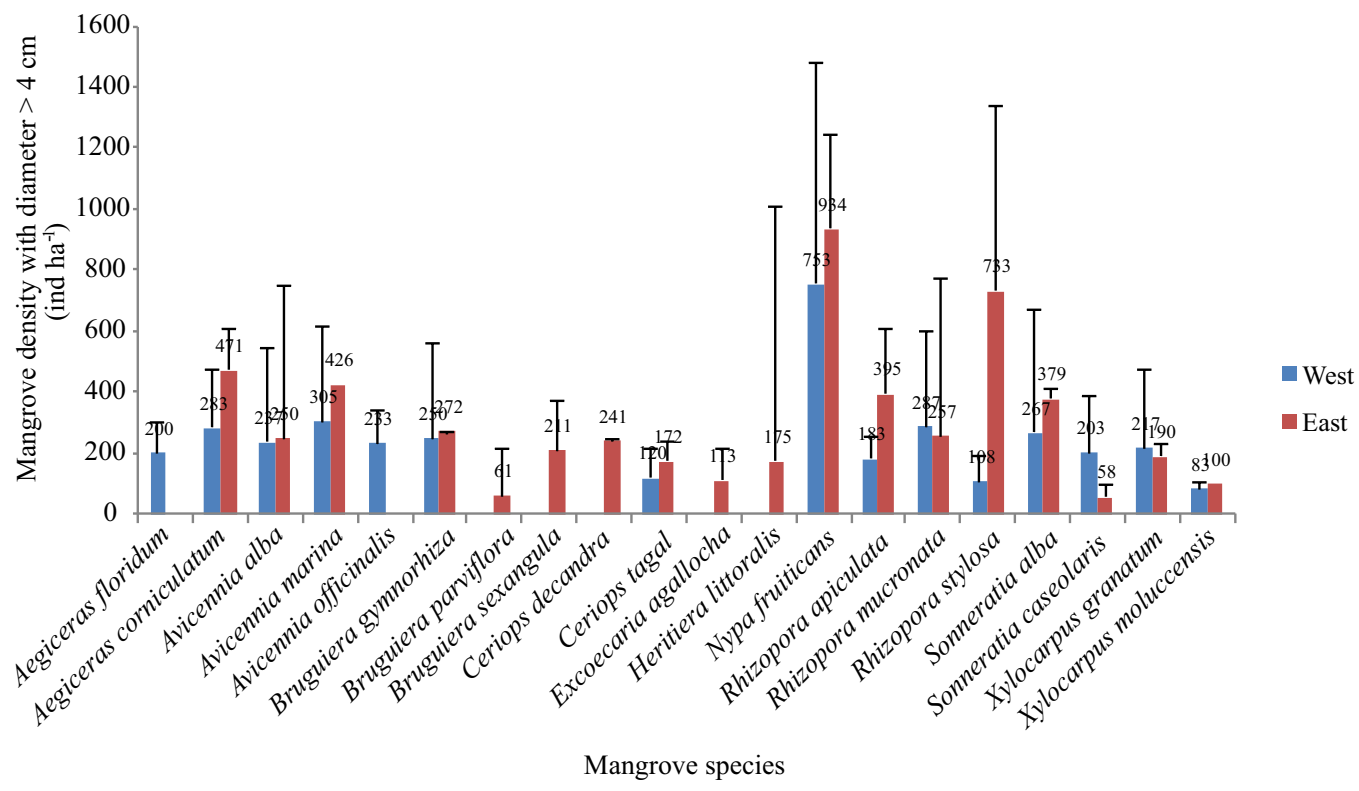

Figure 5 The species density of mangrove ecosystem in Segara Anakan Lagoon.

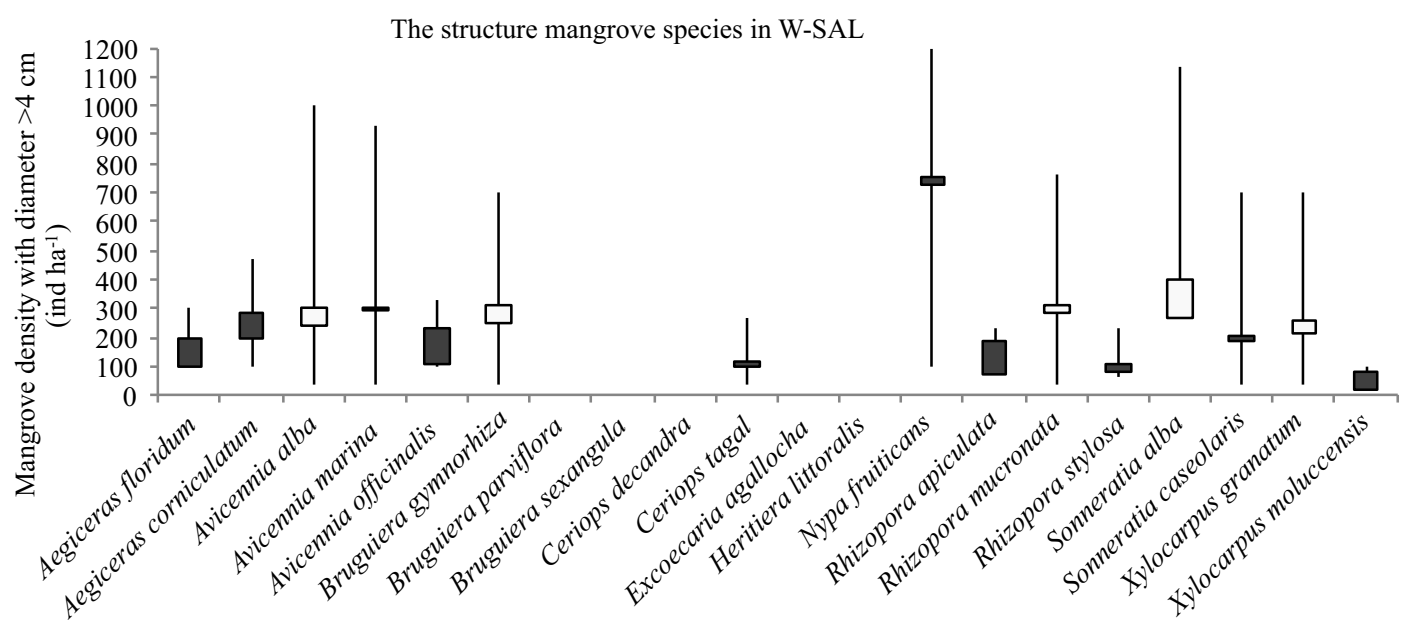

Mangrove species

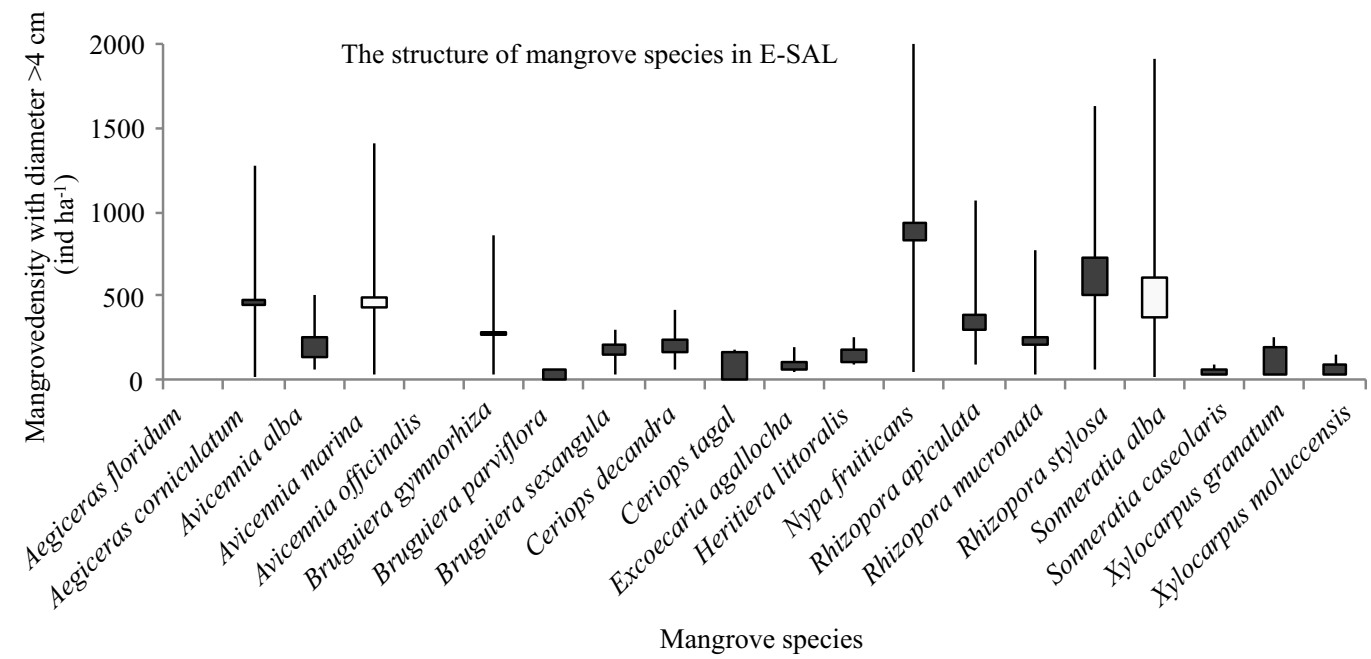

Figure 6 Distribution of mangrove species density in Segara Anakan Lagoon. 
Table 3 The mangrove density and species distribution in SAL

\begin{tabular}{|c|c|c|c|c|c|c|c|}
\hline \multirow{2}{*}{\multicolumn{2}{|c|}{ Density level* }} & \multicolumn{2}{|c|}{ Density (trees ha ${ }^{-1}$ ) } & \multicolumn{2}{|c|}{ Percent covering } & \multicolumn{2}{|c|}{ Species dominant } \\
\hline & & \multirow{2}{*}{$\frac{\text { E-SAL }}{120}$} & \multirow{2}{*}{$\frac{\mathrm{W}-\mathrm{SAL}}{143}$} & \multirow{2}{*}{$\begin{array}{c}\text { E- } \\
\text { SAL } \\
1.2\end{array}$} & \multirow{2}{*}{$\frac{\mathrm{W}-\mathrm{SAL}}{5.0}$} & E-SAL & W-SAL \\
\hline \multirow[b]{2}{*}{$\begin{array}{l}\text { Very rare } \\
\text { density }\end{array}$} & Max & & & & & Xylocarpus & Xylocarpus \\
\hline & Min & 75 & 123 & & & $\begin{array}{l}\text { mollucensis, } \\
\text { Heritiera litoralis, } \\
\text { Sonneratia caseolaris }\end{array}$ & $\begin{array}{l}\text { mollucensis, } \\
\text { Aegiceras floridum, } \\
\text { Rhizophora } \\
\text { apiculata }\end{array}$ \\
\hline \multirow[b]{2}{*}{$\begin{array}{l}\text { Rare } \\
\text { density }\end{array}$} & Max & 950 & 1233 & 11.8 & 55.0 & $\begin{array}{l}\text { Brugueira sexangula, } \\
\text { Xylocarpus }\end{array}$ & $\begin{array}{l}\text { Rhizophora stylosa, } \\
\text { Ceriops tagal, }\end{array}$ \\
\hline & Min & 850 & 543 & & & $\begin{array}{l}\text { granatum, Bruguiera } \\
\text { parviflora }\end{array}$ & $\begin{array}{l}\text { Avicennia } \\
\text { officinalis, } \\
\text { Bruguera } \\
\text { gymnorrhiza, } \\
\text { Aegiceras } \\
\text { corniculatum } \\
\end{array}$ \\
\hline \multirow[b]{2}{*}{ Moderate } & Max & 2,087 & 2,156 & 17.6 & 15.0 & Ceriops decandra, & Xylocarpus \\
\hline & Min & 1,847 & 1,688 & & & $\begin{array}{l}\text { Ceriops tagal, } \\
\text { Avicennia alba }\end{array}$ & $\begin{array}{l}\text { granatum, } \\
\text { Rhizophora } \\
\text { mucronata, } \\
\text { Sonneratia alba, } \\
\text { Avicennia alba }\end{array}$ \\
\hline \multirow{2}{*}{$\begin{array}{l}\text { High } \\
\text { density }\end{array}$} & Max & 3,009 & 2,633 & 35.3 & 15.0 & Bruguiera & Sonneratia \\
\hline & Min & 2,383 & 2,189 & & & gymnorrhiza & caseolaris \\
\hline \multirow[b]{2}{*}{$\begin{array}{l}\text { Very } \\
\text { high } \\
\text { density }\end{array}$} & Max & 4,833 & 3,380 & 34.1 & 10.0 & $\begin{array}{l}\text { Sonneratia alba, } \\
\text { Rhizophora }\end{array}$ & $\begin{array}{l}\text { Avicennia marina, } \\
\text { Nypa frutican }\end{array}$ \\
\hline & Min & 3,264 & 3,286 & & & $\begin{array}{l}\text { mucronata, Avicennia } \\
\text { marina, Rhizophora } \\
\text { apiculata, } \\
\text { Rhizophora stylosa, } \\
\text { Nypa frutican }\end{array}$ & \\
\hline
\end{tabular}

*The grouping of mangrove density used the Hilmi et al. (2020) method

Table 4 Mangrove diversity and diameter distribution in SAL

\begin{tabular}{ccccccccc}
\hline & \multicolumn{4}{c}{ Percent of distribution of diameter class * } & \multicolumn{3}{c}{ Biodiversity } \\
\cline { 2 - 8 } & $0-4$ & $5-9$ & $10-20$ & $21-30$ & $>30$ & Species richness & Heterogenity & Evenness \\
\hline East & 0.3 & 97.3 & 2.1 & 0.3 & 0.0 & 1.70 & 2.57 & 0.87 \\
West & 20.3 & 79.5 & 0.2 & 0.0 & 0.0 & 2.09 & 2.65 & 0.79 \\
\hline
\end{tabular}

are the river current and water depth. The data showed that Segara Anakan Lagoon (SAL) had the river debit of between $0.210 .8 \mathrm{~ms}^{-1}$ and the lagoon optimum water depth of $<23.76$ $\mathrm{m}$. The data were lower than the potential river debit in Cocoa ck (Aucan \& Ridd, 2000). This condition was caused by the existence of Nusakambangan Island as a buffer of SAL from sea current and wind current.

This data showed that Segara Anakan Lagoon is the semi closed hydrodynamic of water current and river debits which is influenced by the interaction among river debit, tidal wave, mangrove ecosystem, sediment distribution, and waste disposal (Hilmi, et al., 2017; Suhendra et al., 2018). Table 3 also showed the river current and river debit in Segara Anakan Lagoon ranging of between $0.340 .75 \mathrm{~m} \mathrm{~s}^{-1}$.
Distribution of soil factors Segara Anakan Lagoon had dominated soil texture was clay and loam; nitrate distribution of between $0.1280 .191 \%$, phosphate of between 9.5614.95\%, C-organic ranging between $1.161 .49 \%$; $\mathrm{pH}$ of between $5.737,53$ and water salinity of between $13.519 .5 \mathrm{ppt}$ (E-SAL) and nitrate distribution of between $0.0780 .133 \%$, phosphate of between $10.4413 .77 \%$, C-organic ranging between 1.161.47\%; pH of between 6.207 .53 , and water salinity of between $13.519 .5 \mathrm{ppt}(\mathrm{W}-\mathrm{SAL})$ (Table 5).

The data showed that (1) C-organic in W-SAL similar value with E-SAL, (2) potential $\mathrm{pH}$ in W-SAL higher than $\mathrm{E}$ SAL, (3) nitrate potential in W-SAL less than E-SAL, (4) water salinity in W-SAL less than E-SAL, and (5) phosphate potential in W-SAL higher than E-SAL. 
Table 5 Sea tides, current, and water depth classification

\begin{tabular}{lll}
\hline Factor & Eastern & Western \\
\hline Sea tide & & \\
Formzahl score & $0.702-0.720$ & $0.1633-0.222$ \\
Sea tide classification & Semi diurnal until mixed & Mixed prevailing semi- \\
& prevailing semi-diurnal & diurnal \\
Sea tide range & $10-403 \mathrm{~cm}$ & $35-165 \mathrm{~cm}$ \\
MSL $(\mathrm{cm})$ & $33-157 \mathrm{~cm}$ & $30-110 \mathrm{~cm}$ \\
\hline Current and water depth & & \\
Current and river debit & $0.34-0.75 \mathrm{~m} \mathrm{~s}^{-1}$ & $0.21-0.8 \mathrm{~m} \mathrm{~s}^{-1}$ \\
Angular direction & $46.85-345.76^{\circ}$ & $15.0-354.0^{\circ}$ \\
Water depth & $<23.76 \mathrm{~m}$ & $<20.2 \mathrm{~m}$ \\
\hline
\end{tabular}

Table 6 Distribution of soil properties

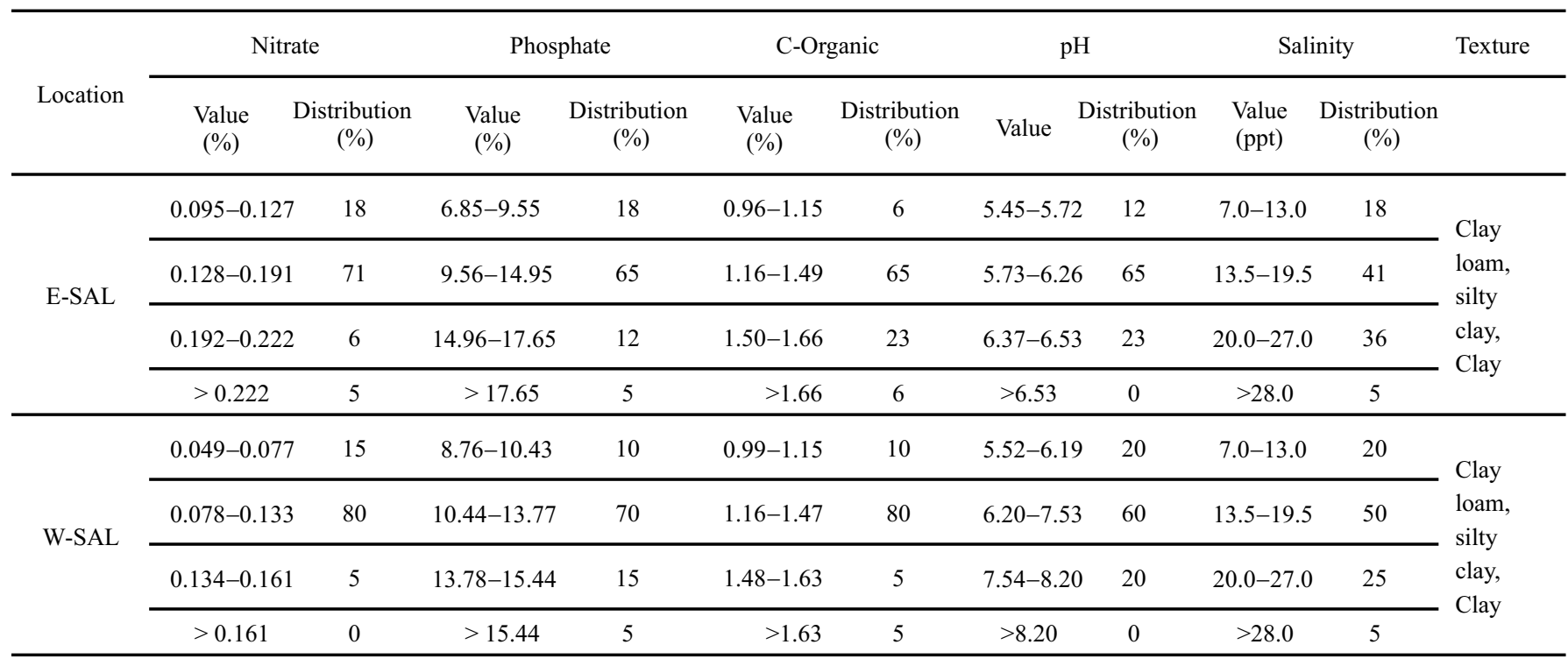

The relation among mangrove zone and landscape with trigerring factors The correlation between mangrove density with trigerring factors showed that dissolve oxygen, water $\mathrm{pH}$, sea tide and soil salinity had moderate correlation with mangrove density (Table 6). According to Kusmana \& Maulina (2015), Nelson et al. (2009), and Hilmi et al. (2017), soil texture and soil salinity have big impact for mangrove distribution and landscape.

Base on data of sea tide, water depth, water current and soil factors in Segara Anakan Lagoon showing the suitable habitat to support mangrove growth. The suitable habitat of mangrove in SAL are shown by the first indicator seatide. Seatide in Segara Anakan semi diurnal to mixed prevailing semi-diurnal tide with data range between $10403 \mathrm{~cm}$ (sea tide) and $30157 \mathrm{~cm}$ (MSL). The seatide condition is very suitable to support mangrove growth (Mazda et al., 2007; Hilmi et al., 2015).

The second indicator is the river current and water depth. The potential river current between $0.210 .8 \mathrm{~m} \mathrm{~s}^{-1}$ and the lagoon optimum water depth of $<23.76 \mathrm{~m}$ is very suitable condition to support mangrove live. Cahyo, (2012) also writes that the W-SAL has current and river debits $0,6768 \mathrm{~m}$ $\mathrm{s}^{-1}$ with direction 240,1 (southwest) (low tide) and $0,1578 \mathrm{~m} \mathrm{~s}^{-}$ ${ }^{1}$ with direction 8,3 (north) (high tide).
The last indicators are distribution of soil factors. Soil factors like as soil salinity, $\mathrm{pH}$, and soil texture have high influence to develop the species distribution in mangrove ecosystem (Castillo et al., 2017; Datta \& Deb, 2017). Kusmana and Maulina (2015) stated salinity as first soil indicator is a big factor to influence mangrove distribution, because salinity causes disseminating mangrove plants, canopy opening, species distribution, species density, species composition and inhibiting nitrogen assimilation, and mangrove plants grow well with the salinity of $1030 \mathrm{ppt}$. The second factor is soil pH. The soil pH in Segara Anakan Lagoon had ranges between 5.796.27 (acid-neutral). Hilmi et al. (2019a) stated that mangrove grows well on $\mathrm{pH}$ of between 68.5. Then, the other soil properties are Nitrate, Phosphate and C-organic. These data showed that Segara Anakan had high soil fertility to support the mangrove growth (Xiong et al., 2018), because SAL had the nitrate of between $0.110 .33 \%$ (highly potential); phosphate of between $9.4713 .8 \%$ (highly potential) and C-organic of between $1.151 .48 \%$.

Mangrove landscape in Segara Anakan Lagoon Species distribution of mangrove ecosystem in Segara Anakan Lagoon (SAL) was divided into three classes that were (1) 
dominant species consisting of A. alba, A. marina, $N$. frutican, $R$. apiculata, and $R$. mucronata; (2) co-dominant species consisting of $S$. alba, S. caseolaris, B. gymorrhiza, $C$. tagal, A. Cornicultum, B. sexangula, C. decandra, and $B$. praviflora; and (3) minor species consisting of Heritiera littolaris, Exocecaria agallocha, and Xylocarpus granatum (Table 7).

The dominant species on mangrove ecosystem showing best species adaptation to life in Segara Anakan. The mangrove ecosystem in SAL had potential of sea tide $(50-200 \mathrm{~cm})$, water inundation $(076 \mathrm{~cm})$, potential soil nitrate $(0.15-0.29 \%)$, soil phosphate $(8.5-16.5 \%)$, soil salinity $(7.0>28 \mathrm{ppt})$, and $\mathrm{pH}(5.5-7.5)$. Based on the indicators of dominant species, species density, adaptation of soil salinity, soil $\mathrm{pH}$, soil nitrate, soil phosphate, C-organic, sea tide and water depth, developing of the mangrove landscape in SAL can be shown in Figure 8.

The mangrove landscape patterns in SAL describe specific distribution of mangrove species, which were influenced by species adaptation toward soil properties, oceanography factors and water quality. The mangrove landscape in Segara Anakan Lagoon consisted of Zone 1: $A$. marina, A. alba, S. alba, $R$. mucronata, $R$ apiculata, $R$. stylosa, $A$. corniculatum, $C$. decandra; Zone 2: A. marina, $A$. alba, S. alba, R. mucronata, $R$. apiculata, R. stylosa, B. gymnorrhiza, A. corniculatum, C. tagal, X. granatum, $C$. decandra, E. agallocha; Zone 3: $R$. apiculata, $R$. mucronata, R. stylosa, B. gymnorrhiza, B. sexangula, $A$. corniculatum, C. tagal, E. agallocha, X. granatum, $N$. frutican, $H$. littoralis; Zone 4: $R$. apiculata, $R$. mucronata,

Table 7 Correlation index mangrove density and trigering factors

\begin{tabular}{|c|c|c|c|c|}
\hline \multirow{10}{*}{$\begin{array}{l}\text { Correlation } \\
\text { with } \\
\text { mangrove } \\
\text { density }\end{array}$} & \multicolumn{2}{|c|}{ Class correlation } & Correlation coeficient & Environment variables \\
\hline & \multirow{2}{*}{$\begin{array}{l}\text { Type of } \\
\text { correlation }\end{array}$} & Positive & 0.0360 to 0.4960 & Water temperature, soil organic, soil salinity, soil $\mathrm{pH}$ \\
\hline & & Negative & -0.0679 to -0.5942 & $\begin{array}{l}\text { Dissolve oxygen, water } \mathrm{pH} \text {, water salinity, nitrate, } \\
\text { phosphate, water depth, seatide }\end{array}$ \\
\hline & \multirow{7}{*}{$\begin{array}{l}\text { Grade of } \\
\text { correlation* }\end{array}$} & Absolute & 1 & \\
\hline & & Very high & $0.8-<1$ & \\
\hline & & High & $0.6-<0.8$ & \\
\hline & & Moderate & $0.4-<0.6$ & Dissolve oxygen, C-organic \\
\hline & & Low & $0.2-<0.4$ & Water temperature, soil $\mathrm{pH}$, water $\mathrm{pH}$, nitrate, soil sal \\
\hline & & Very low & $0.0-<0.2$ & water salinity, phosphate \\
\hline & & Uncorrelated & 0 & \\
\hline
\end{tabular}

*Following Walpole and Myers (1995)

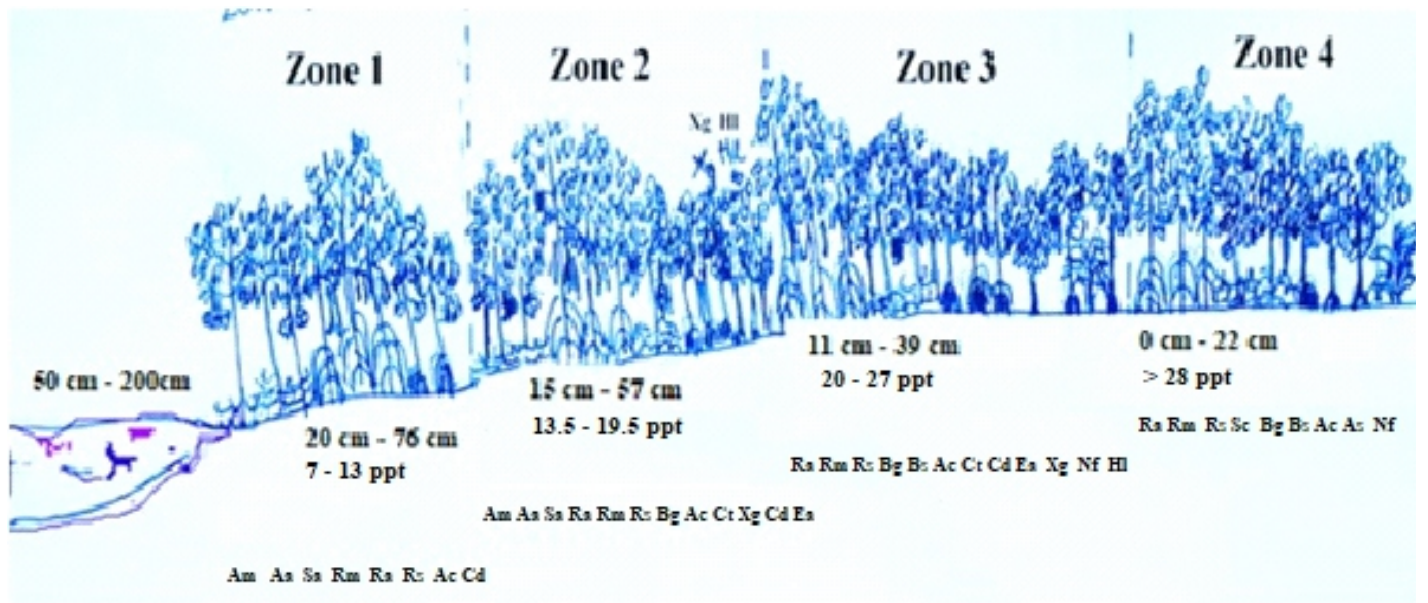

Note: A. corniculatum (Ac), Alstonia scholaris (As), A. alba (Aa), A. marina (Am), B. gymnorrhiza (Bg), B. sexangula (Bs), C. decandra $(\mathrm{Cd}), C$. tagal $(\mathrm{Ct})$, Exoecaria agallocha $(\mathrm{Ea})$, H. Littorea $(\mathrm{Hl})$, N. frutican $(\mathrm{Nf})$, R. Mucronata $(\mathrm{Rm})$, R. Apiculata (Ra), R. Styllosa (Rs), S. alba (Sa), S. caseolaris (Sc), Xylocarpus molucensis (Xm)

Figure 8 The pattern of mangrove landscape. 
R. stylosa, B. gymnorrhiza, B. sexangula, A. corniculatum, $S$. caseolaris, A. scolaris, and $N$. frutican.

The mangrove landscape in Segara Anakan Lagoon had different patterns with the mangrove landscaping proposed by Waston (1928) and Snedaker (1982), because this pattern used the combination of environmental factors (seawater tide, water inundation, texture, and soil water salinity) with the existence of domination, co-domination, and minor species. This landscape also describe specific distribution of mangrove species in Segara Anakan Lagoon. The specific distribution was arraanged by ability of mangrove species to life and grow in other zones, like as $R$. apiculata, $R$. mucronata, and R. stylosa. However, Waston (1928) used only water inundation as the main factor. But, basically, water inundation also impacts on water circulation, potential oxygen, and nutrient supply, water salinity, sediment transportation, $\mathrm{pH}$, and soil texture (Asaeda \& Barnuevo, 2019). Water inundation significantly influences the mangrove growth (Hoppe-Speer et al., 2011; Kusmana \& Maulina, 2015), maximum photosynthesis process, and stomata opening (Hoppe-Speer et al., 2011). Snedaker (1982) also writes zonation as an expression of plant succession, a response to geomorphic change, physiological response to tide maintained gradients and a consequence of differential propagule dispersal only describe mangrove zonation following mangrove forest type, abundance propagule dispersal, light appears, distribution substrate, salinity, and sea tide factor.

The other reasons to describe different patern between mangrove landscaping in SAL with Waston (1928) patern, because the mangrove landscaping in SAL was influenced by mangrove degradation with degradation rate 108.87 ha year $^{-1}$, combine oceanografic factors between seatide, water depth, water inundation and rivers current. This factors will influencing mangrove adaptation and mangrove regeneration (Mazda et al., 2007) to adapt supply of phosphate, sulfate, nitrogen, and nitrate (Hoppe-Speer et al., 2011; Shiau et al., 2017b; Cheng et al., 2019; Wang et al., 2019), fresh water supply (Barreto et al., 2016; Dai et al., 2018; Xiong et al., 2018), water $\mathrm{pH}$ and water salinity (Khadim et al., 2019), and the other factors are the soil properties. Xiong et al. (2018) noted that based on the perspective of salinity, texture and soil fertility, Segara Anakan Lagoon is adequately available to support the mangrove growth, because has suitable salinity (betwen $435 \mathrm{ppt}$ ), suitable $\mathrm{pH}$ (between 6.0-90), suitable texture (clay and clay loam), and moderatehigh potential of C-organic, phosaphate, and N total (Djohan, 2012; Kusmana \& Maulina, 2015; Xiong et al., 2018).

\section{Conclusion}

$A$. alba, A. marina, $N$. frutican, $R$ apiculate, and $R$. mucronata are dominant species in Segara Anakan Lagoon, whereas S. alba, S. caseolaris, B. gymorrhiza, C. tagal, A. cornicultum, B. sexangula, $C$. decandra, and B. parviflora are co-dominant species. H. littolaris, E. agallocha, and $X$. granatum are minor species. Mangrove landscape in SAL has a spesific patern following the ability of mangrove species to life in many zonations. Mangrove landscape in Segara Anakan Lagoon divided into 4 zones, that are Zone 1 includes A. marina, A. alba, S. alba, R. mucronata, R. apiculata, $R$. stylosa, A. corniculatum, C. decandra; Zone 2 includes $A$. marina, A. alba, S. alba, R. mucronata, R. apiculata, $R$. stylosa, B. gymnorrhiza, A. corniculatum, C. tagal, X. granatum, $C$. decandra, E. agallocha; Zone 3 can be grow by $R$. apiculata, $R$. mucronata, $R$. stylosa, B. gymnorrhiza, $B$. sexangula, A. corniculatum, C. tagal, E. agallocha, X. granatum, $N$. frutican, $H$. littoralis; Zone 4 includes $R$. apiculata, R. mucronata, R. stylosa, B. gymnorrhiza, B. sexangula, A. corniculatum, $S$. caseolaris, A. scolaris, and $N$. frutican.

\section{Recommendation}

The mangrove landscape uses several indictors of environment factors, mangrove density and species distribution can be used to support mangrove rehabilitation program. The mangrove landscape also is used to support mangrove dynamic activity and to draw mangrove adaptation in the mangrove ecosystem.

\section{Acknowledgment}

The authors would like to deliver special thanks to UNSOED to support this research through the Unsoed Grant (Riset Terapan Unsoed, 2021) Mr. Isdy Sulistyo as the Dean of Fisheries and Marine Science Faculty, Unsoed and LPPM Unsoed. The gratitude also goes to the researcher colleagues for their valuable advices. The authors would also like to thank the anonymous reviewers for helps and constructive comments, which greatly improved the manuscript.

\section{References}

Anthony, E. J. (2004). Sediment dynamics and morphological stability of estuarine mangrove swamps in Sherbro Bay, West Africa. Marine Geology, 208(2-4), 207-224. https://doi.org/10.1016/j.margeo.2004.04.009

[APHA] American Public Health Association. (2005). Standard methods for the examination of water and waste water. (21th ed.). New York: American Water Works Association Water Pollution Control Federation.

[APHA] American Public Health Association. (2012). Standar methods for the examination of water and waste water. (22th ed.). New York: American Water Works Association Water Pollution Control Federation.

Asaeda, T., \& Barnuevo, A. (2019). Oxidative stress as an indicator of niche-width preference of mangrove Rhizophora stylosa. Forest Ecology and Management, 432, 73-82. https://doi.org/10.1016/j.foreco.2018. 09.015

Aucan, J., \& Ridd, P. V. (2000). Tidal asymmetry in creeks surrounded by saltflats and mangroves with small swamp slopes. Wetlands Ecology and Management, 8, 223-231. https://doi.org/10.1023/A:1008459814925

Barreto, M. B., Lo Mónaco, S., Díaz, R., Barreto-Pittol, E., López, L., \& Peralba, M. do C. R. (2016). Soil organic carbon of mangrove forests (Rhizophora and Avicennia) 
of the Venezuelan Caribbean coast. Organic Geochemistry, 100, 51-61. https://doi.org/10.1016/ j.orggeochem.2016.08.002

Cahyo, T. N. (2012). Hidrodinamika dan sebaran materi padatan tersuspensi di perairan Pelawangan Barat, Segara Anakan Cilacap [thesis]. Bogor: IPB University.

Castillo, J. A. A., Apan, A. A., Maraseni, T. N., \& Salmo, S. G. (2017). Soil C quantities of mangrove forests, their competing land uses, and their spatial distribution in the coast of Honda Bay, Philippines. Geoderma, 293, 82-90. https://doi.org/10.1016/j.geoderma.2017.01.025

Cheng, J., Xue, L., Zhu, M., Feng, J., Shen-Tu, J., Xu, J., ..., \& He, Y. (2019). Nitrate supply and sulfate-reducing suppression facilitate the removal of pentachlorophenol in a flooded mangrove soil. Environmental Pollution, 244, 792-800. https://doi.org/10.1016/j.envpol.2018. 09.143

Dai, Z., Trettin, C. C., Frolking, S., \& Birdsey, R. A. (2018). Mangrove carbon assessment tool: Model development and sensitivity analysis. Estuarine, Coastal and Shelf Science, 208,23-35. https://doi.org/10.1016/j.ecss.2018. 04.035

Datta, D., \& Deb, S. (2017). Forest structure and soil properties of mangrove ecosystems under different management scenarios: Experiences from the intensely humanized landscape of Indian Sunderbans. Ocean and Coastal Management, 140, 22-33. https://doi.org/ 10.1016/j.ocecoaman.2017.02.022

de Oliveira, D. C. M., Correia, R. R. S., Marinho, C. C., \& Guimarães, J. R. D. (2015). Mercury methylation in sediments of a Brazilian mangrove under different vegetation covers and salinities. Chemosphere, 127, 214-221. https://doi.org/10.1016/j.chemosphere.2015. 02.009

De Valck, J., \& Rolfe, J. (2018). Linking water quality impacts and benefits of ecosystem services in the Great Barrier Reef. Marine Pollution Bulletin, 130, 55-66. https://doi.org/10.1016/j.marpolbul.2018.03.017

Djohan, T. S. (2012). Distribution and abundance of mangrove vegetation in the disturbed ecosystem of Segara Anakan, Central Java. Jurnal Manusia dan Lingkungan, 19(3), 294-302. https://doi.org/10.22146/ jml.18467

Domínguez-domínguez, M., Zavala-cruz, J., Rincónramírez, J. A., \& Martínez-zurimendi, P. (2019). Management strategies for the conservation, restoration and utilization of mangroves in Southeastern Mexico. Wetlands, 39, 907-919. https://doi.org/10.1007/s13157019-01136-z

Ferreira, A. C., Ganade, G., \& Luiz de Attayde, J. (2015). Restoration versus natural regeneration in a neotropical mangrove: Effects on plant biomass and crab communities. Ocean and Coastal Management, 110, 38-45. https://doi.org/10.1016/j.ocecoaman.2015. 03.006

Giri, C., Long, J., Abbas, S., Murali, R. M., Qamer, F. M., Pengra, B., \& Thau, D. (2015). Distribution and dynamics of mangrove forests of South Asia. Journal of Environmental Management, 148, 101-111. https://doi.org/10.1016/j.jenvman.2014.01.020

Haslwanter, T. (2015). An introduction to statistics with Python, with applications in the life sciences. (W. K. Härdle, Ed.). Springer Natur. https://doi.org/10.1007/ 978-3-319-28316-6

Hidayati, N. V., Hilmi, E., Haris, A., Effendi, H., Guiliano, M., Doumenq, P., \& Syakti, A. D. (2011). Fluorene removal by biosurfactants producing Bacillus megaterium. Waste and Biomass Valorization, 2(4), 415-422. https://doi.org/10.1007/s12649-011-9085-3

Hilmi, E. (2018). Mangrove landscaping using the modulus of elasticity and rupture properties to reduce coastal disaster risk. Ocean and Coastal Management, 165, 71-79. https://doi.org/10.1016/ j.ocecoaman.2018.08. 002

Hilmi, E., Pareng, R., Vikaliana, R., Kusmana, C., Iskandar, Sari, L. K., \& Setijanto. (2017). The carbon conservation of mangrove ecosystem applied REDD program. Regional Studies in Marine Science, 16, 152-161. https://doi.org/10.1016/j.rsma.2017.08.005

Hilmi, E., Sari, L. K., \& Amron. (2020). Distribusi sebaran mangrove dan faktor lingkungan pada ekosistem mangrove Segara Anakan Cilacap (pp 23-33). Prosiding Seminar Nasional Pengembangan Sumber Daya Perdesaan dan Kearifan Lokal Berkelanjutan IX. Purwokerto: Lembaga Penelitian dan Pengabdian pada Masyarakat. Universitas Jenderal Soedirman.

Hilmi, E., Sari, L. K., Cahyo, T. N., Kusmana, C., \& Suhendang, E. (2019a). Carbon sequestration of mangrove ecosystem in Segara Anakan Lagoon, Indonesia. BIOTROPIA: The Southeast Asian Journal of Tropical Biology, 3, 181-190. https://doi.org/10.11598/ btb.2019.26.3.1099

Hilmi, E., Sari, L. K., \& Setijanto. (2019b). The mangrove landscaping based on water quality (Case study in Segara Anakan Lagoon and Meranti Island). IOP Conference Series: Earth and Environmental Science, 255(1), 012028. https://doi.org/10.1088/1755-1315/255/1/ 012028

Hilmi, E., Siregar, A. S., Febryanni, L., Novaliani, R., Amir, S. A., \& Syakti, A. D. (2015). Struktur komunitas, zonasi dan keanekaragaman hayati vegetasi mangrove di Segara Anakan Cilacap. Omni-Akuatika, 11(2), 20-32. https://doi.org/10.20884/1.oa.2015.11.2.36

Hilmi, E., Siregar, A. S., \& Syakti, A. D. (2017). Lead (Pb) 
distribution on soil, water and mangrove vegetation matrices in eastern part of Segara Anakan Lagoon, Cilacap. Omni-Akuatika, 13(2), 25-38. http://ojs.omniakuatika.net/index.php/joa/article/downlo $\mathrm{ad} / 83 / 129$

Hoppe-Speer, S. C. L., Adams, J. B., Rajkaran, A., \& Bailey, D. (2011). The response of the red mangrove Rhizophora mucronata Lam. to salinity and inundation in South Africa. Aquatic Botany, 95(2), 71-76. https://doi.org/ 10.1016/j.aquabot.2011.03.006

Kantharajan, G., Pandey, P. K., Krishnan, P., Ragavan, P., Jeevamani, J. J. J., Purvaja, R., \& Ramesh, R. (2018). Vegetative structure and species composition of mangroves along the Mumbai coast, Maharashtra, India. Regional Studies in Marine Science, 19, 1-8. https://doi.org/10.1016/j.rsma.2018.02.011

Khadim, F. K., Su, H., Xu, L., \& Tian, J. (2019). Soil salinity mapping in Everglades National Park using remote sensing techniques and vegetation salt tolerance. Physics and Chemistry of the Earth, 110, 31-50. https://doi.org/ 10.1016/j.pce.2019.01.004

Kusmana, C., \& Maulina, S. (2015). Respon pertumbuhan semai bakau (Rhizophora mucronata Lamk.) terhadap tingkat kedalaman dan lama penggenangan. Jurnal Silvikultur Tropika, 5(3), 155-159.

Liu, L., Yao, S., Zhang, H., Muhammed, A., Xu, J., Li, R., ..., \& Yang, X. (2019). Soil nitrate nitrogen buffer capacity and environmentally safe nitrogen rate for winter wheatsummer maize cropping in Northern China. Agricultural Water Management, 213, 445-453. https://doi.org/ 10.1016/j.agwat.2018.11.001

Magurran, A. (1996). Ecological diversity and its measurement. Berlin: Springer

Mazda, Y., Wolanski, E., \& Ridd, P. (2007). The role of physical processes in mangrove environments. Tokyo: Terrapub.

Nelson, M., Dempster, W. F., \& Allen, J. P. (2009). The water cycle in closed ecological systems: Perspectives from the Biosphere 2 and Laboratory Biosphere systems. Advances in Space Research, 44(12), 1404-1412. https://doi.org/10.1016/j.asr.2009.06.008

Sari, L. K., Adrianto, L., Soewardi, K., Atmadipoera, A. S., \& Hilmi, E. (2016). Sedimentation in lagoon waters (Case study on Segara Anakan Lagoon). AIP Conference Proceedings, 17-30.https://doi.org/10.1063/1.4947417

Schwarzer, K., Thanh, N. C., \& Ricklefs, K. (2016). Sediment re-deposition in the mangrove environment of Can Gio, Saigon River estuary (Vietnam). Journal of Coastal Research, 75(sp1), 138-142. https://doi.org/ $10.2112 /$ si75-028.1

Shiau, Y. J., Lee, S. C., Chen, T. H., Tian, G., \& Chiu, C. Y. (2017a). Water salinity effects on growth and nitrogen assimilation rate of mangrove (Kandelia candel) seedlings. Aquatic Botany, 137, 50-55. https://doi.org/ 10.1016/j.aquabot.2016.11.008

Shiau, Y. J., Lin, M. F., Tan, C. C., Tian, G., \& Chiu, C. Y. (2017b). Assessing N2 fixation in estuarine mangrove soils. Estuarine, Coastal and Shelf Science, 189, 84-89. https://doi.org/10.1016/j.ecss.2017.03.005

Sinfuego, K. S., \& Buot, I. E. (2014). Mangrove zonation and utilization by the local people in Ajuy and Pedada Bays, Panay Island, Philippines. Journal of Marine and Island Cultures, 3(1), 1-8. https://doi.org/10.1016/j.imic.2013. 11.002

Singh, S. K., Srivastava, P. K., Thakur, J. K., \& Mukherjee, S. (2013). Appraisal of land use/land cover of mangrove forest ecosystem using support vector machine. Environmental Earth Sciences, 71, 2245-2255. https://doi.org/10.1007/s12665-013-2628-0

Smee, D. L., Sanchez, J. A., Diskin, M., \& Trettin, C. (2017). Mangrove expansion into salt marshes alters associated faunal communities. Estuarine, Coastal and Shelf Science, 187, 306-313. https://doi.org/10.1016/j.ecss. 2017.02.005

Sreelekshmi, S., Preethy, C. M., Varghese, R., Joseph, P., Asha, C. V., Bijoy Nandan, S., \& Radhakrishnan, C. K. (2018). Diversity, stand structure, and zonation pattern of mangroves in southwest coast of India. Journal of AsiaPacific Biodiversity, 11(4), 573-582. https://doi.org/ 10.1016/j.japb.2018.08.001

Suhendra, Amron, A., \& Hilmi, E. (2018). The pattern of coastline change based on the characteristics of sediment and coastal slope in Pangenan coast of Cirebon, West Java. E3S Web of Conferences, 47. https://doi.org/ $10.1051 / \mathrm{e} 3$ sconf $/ 20184706001$

Syakti, A. D., Ahmed, M. M., Hidayati, N. V., Hilmi, E., Sulystyo, I., Piram, A., \& Doumenq, P. (2013a). Screening of Emerging Pollutants in the Mangrove of Segara Anakan Nature Reserve, Indonesia. IERI Procedia, 5, 216-222. https://doi.org/10.1016/j.ieri. 2013.11.095

Syakti, A. D., Hidayati, N. V., Hilmi, E., Piram, A., \& Doumenq, P. (2013b). Source apportionment of sedimentary hydrocarbons in the Segara Anakan Nature Reserve, Indonesia. Marine Pollution Bulletin, 74(1), 141-148. https://doi.org/10.1016/j.marpolbul.2013. 07.015

Victor, S., Neth, L., Golbuu, Y., Wolanski, E., \& Richmond, R. H. (2006). Sedimentation in mangroves and coral reefs in a wet tropical island, Pohnpei, Micronesia. Estuarine, Coastal and Shelf Science, 66(34), 409-416. https://doi.org/10.1016/j.ecss.2005.07.025

Wang, Y., Ying, H., Yin, Y., Zheng, H., \& Cui, Z. (2019). 
Estimating soil nitrate leaching of nitrogen fertilizer from global meta-analysis. Science of the Total Environment, 657, 96-102. https://doi.org/10.1016/j.scitotenv.2018. 12.029

Waston, J. G. (1928). Mangrove forest on Malay Penninsula. Malay Record, 6, 1-127.

Xin, K., Huang, X., Hu, J., Li, C., Yang, X., \& Arndt, S. K. (2014). Land use change impacts on heavy metal sedimentation in mangrove wetlands - A case study in Dongzhai Harbor of Hainan, China. Wetlands, 34, 1-8. https://doi.org/10.1007/s13157-013-0472-3

Xiong, Y., Liao, B., Proffitt, E., Guan, W., Sun, Y., Wang, F., \& Liu, X. (2018). Soil carbon storage in mangroves is primarily controlled by soil properties: A study at Dongzhai Bay, China. Science of the Total Environment, 619-620, 1226-1235. https://doi.org/10.1016/j.scitotenv. 2017.11.187 